\title{
Pedagogical Approaches of Intermediate Schoolteachers for Teaching Students by Building Online Classroom Communities during the COVID-19 Pandemic
}

\author{
Ebrahim Ghazi Alenezi * \\ Public Authority for Applied Education and Training, Alardiya, KUWAIT \\ E-mail: Ig.alenezi@paaet.edu.kw \\ Dr John Woollard \\ Centre for Research on Inclusion, University of Southampton, UK \\ E-mail: J.Woollard@southampton.ac.uk \\ Dr Yousif Hadi Alenezi \\ Assistant Professor, College of Basic Education, Kuwait \\ E-mail: Y.alenezi@paaet.edu.kw \\ Dr Dalal Farhan Alenezi \\ Associated Professor, College of Basic Education, Kuwait \\ E-mail: Df.alenezi@paaet.edu.kw
}

The research is financed by Asian Development Bank. No. 2006-A171(Sponsoring information)

\section{Abstract}

This study explores teachers' perceptions of their pedagogical approaches for teaching students by connecting and building online classroom communities in distance education programs during the COVID-19 pandemic. Participants in this study are teachers from 12 intermediate schools in Kuwait. The study generates survey data from 153 teachers ( 93 females and 60 males) to determine teachers' perceptions of their pedagogical beliefs, mode of delivery and communication, patterns of interaction and guided inquiry. The findings of the study suggest that teachers are willing to use technology and different modes of communication to connect with students and deliver remote instruction during the COVID-19 pandemic. Although teachers did combine some aspects of both traditional and constructivist approaches and were willing to use technology to bridge the distance created by remote education, they were averse to teaching online and considered face-to-face interaction with students essential. While it is evident that there will be a continuum of technology-based instruction when the teachers transition from face-to-face teaching to fully online remote teaching, the teachers were not aware of interaction patterns which are critical in online distance education. ANOVA results indicate there is no significant difference in the participants' opinions on interaction patterns based on teachers' experience and courses they taught $(\mathrm{p}=>.05)$. The descriptive data and the results of ANOVA and Tukey indicate that most teachers, irrespective of their subject specializations or experience, did not consider guided inquiry to be important for distance education. This study has implications for supporting effective technology integration for the delivery of instruction during a pandemic. Keywords: Pandemic, COVID-19, Remote Teaching, Distance Learning, Pedagogical Beliefs, Pedagogical Approaches, Interaction Patterns, Guided Inquiry, Communities of Inquiry, TPACK, Practical subject (Electrical) DOI: $10.7176 / \mathrm{JEP} / 11-30-02$

Publication date:October $31^{\text {st }} 2020$

\section{Introduction and background}

COVID-19, a contagious and acute respiratory disease with a high fatality rate, has now become a major public health challenge resulting in the global disruption of education (Abiad et al. 2020). Although it originated in Wuhan, China, the virus and the lockdowns that ensued have caused educational institutions world-wide to move teaching online on an untested and staggering scale (Burgess \& Sievertsen, 2020). The overall objective of moving online is to continue education without contact between people to help slow the pandemic and save human lives. The direct consequence is to force teachers and administrators to utilise communication technology in teaching. The recognition of the affordances might impact on future practice in the "new normal" of teaching.

Although, moving instruction online can enable the flexibility of teaching and learning anywhere, anytime, the previous pace of change in Kuwaiti educational institutions is has been slow. Teacher-centric approaches and outmoded classrooms are prevalent (Alenezi, 2018; Almodaires, Alayyar, Almsaud \& Almutairi, 2019; Alfelaij, 2016). However, COVID-19 could become a catalyst for educational institutions in Kuwait, and worldwide, to identify and implement innovative solutions in a relatively short period of time (Bates, 2020). The pandemic has already revitalized the need to study and analyze the affordances of distance teaching and learning approaches as 
alternatives to traditional face-to-face classroom instruction (EPALE, 2020; World Bank, 2020). The current situation could be used to test the effectiveness of technology interventions for distance learning, and to plan for sustainable, quality, flexible learning options and most importantly the development of communities of learning (Bates, 2020; Naidu, 2017).

The aim of this research is to investigate the pedagogical approaches that best support effective use of technologies to connect with students and build classroom communities during the COVID-19 pandemic in a remote learning context. This research explores teachers' perceptions and if they are aware of basic concepts to implement distance learning rapidly. The following sections synthesize the existing distance education research in general as well as synchronous and asynchronous online learning, which are key for connecting with students to build online classroom communities (Yamagata-Lynch, 2018; Abdelmalak, 2015; Clark, Strudler \& Grove, 2015).

\section{Pedagogical approaches for distance learning}

There are key issues when considering the pedagogy of distance learning: the physicality of presence, teachers' beliefs in the traditional ways of working, enforced change-of-practice and the affordances of personalized technology-based interfaces.

Distance education focuses on the pedagogy, technology, and instructional systems design that are combined to provide education to learners who are not physically present in classrooms (Tomei, 2010). Guilar and Loring (2008, p.21) defined distance education as learning that "occurs when learners and faculty do not meet face-toface in the same physical space" (p. 19). Distance education is associated with the lack of physical contact and social isolation (Raheva, 2018). It is said to comprise two broad communication approaches: synchronous and asynchronous. Synchronized or instructor-led and facilitated e-learning is claimed to occur when a group of students and a teacher interact, and learning takes place in real-time (Raes, Detienne, Windey \& Depaepe, 2019). Synchronous learning is generally suitable for students who intend to schedule a time or day for their studies. However, the courses have to be structured as the students are learning from a distance and the teachers can connect, create community of learners and help them engage in meaningful learning (Yamagata-Lynch, 2018). Most importantly, students can interact with the teacher or with peers and learn in real-time. This is in line with social constructivist theory of learning. Asynchronized or self-paced learning which stems from constructivist learning theory allows students to access online content or participate in learning from anywhere and at their convenience, independent of the teacher. One of the merits of asynchronized learning is that it gives the learners great flexibility in term of learning time, process and content (Dada, Alkali \& Oyewola, 2019). Whether the distance learning environment is synchronous or asynchronous, teachers have to put forth a strong presence, even in an online course. They can rely on synchronous, asynchronous or a combination of the two approaches. Experts say the best recipe for success is to mix the two learning approaches (Yamagata-Lynch, 2018). Too much synchronous teaching, for instance a lengthy virtual meeting may suggest that teachers expect students to attend in full and therefore could be extremely thought-provoking for students and frustrating for teachers alike. It is also argued that teachers have to focus on the content (Content Knowledge and Pedagogical Content Knowledge), delivery (Technological Knowledge) and coordination of the learning environment (Technological Pedagogical and Content Knowledge or TPACK) (Garrison, Baia, Canning \& Strang, 2015; Mishra \& Koehler, 2006). This requires significant changes to pedagogy and a new pedagogy has to be triggered not just by student expectations, but by collaborative approaches to the construction of knowledge/building and creating communities of learning by integrating new technologies. For example, Google Classroom a new tool can be incorporated into classrooms with little understanding about their impact on actual teaching and learning practice (Heggart \& Yoo, 2018). Distance learning is being integrated into broader education systems because digital education promotes flexible learning (Zhang, Burgos \& Dawson, 2019). It is claimed that flexible learning allows for flexibility of time, place, pace of study and audience (Cassidy et al. 2016; Naidu, 2017). While experimenting with open and flexible learning and teaching models and technologies that can create socially engaged and active learning contexts, the current circumstances will no doubt highlight issues of access and equity to technology as well as the skills and knowledge of teachers to use technology for teaching and learning (Zhang et al., 2019; Roulston et al., 2019; Al-Awidi \& Aldhafeeri, 2017).

Teachers' pedagogical orientations for using technology are based on their beliefs and therefore they still tend to replicate traditional practices. Carmo and Franco (2019) found that teachers show preference for face-to-face interactions with students as they believe that in interactions mediated by technology there is an absence of the individuals' direct physical presence or body language elements. Prestridge (2017) conducted a two-year case study of three teachers to examine the relationship between teachers' pedagogical beliefs and practices about the use of technologies. The study found that such a relationship existed and that teachers' beliefs shaped their pedagogical orientation for the use of technology. Tarling and Ng'ambi (2016) argue that shaping a teachers' pedagogical orientation requires fundamentally altering the role of the teacher from that of a sage-on the-stage to that of a guide-on-the-side. However, this requires technological competence (Carmo \& Franco, 2019). Other factors that influence teachers' pedagogical orientations are discrepancies between professional development and school 
culture, and other personal constraint (Bansal, Ramnarain \& Schuster, 2019).

The enforced distance learning during the pandemic provides a unique context during which teachers can adopt constructivist principles. In other words, the need for teachers to utilise technology for communication with learners naturally leads to the incorporation of constructivist-based learning theory with distance learning where learners are at the center of the learning (Dagar \& Yadav, 2016). Research has shown that teachers with constructivist-oriented pedagogical beliefs are significantly more likely to use technology than transmissionoriented teachers (Burke, Schuck, Aubusson, Kearney \& Frischknecht, 2018). A social constructivism pedagogy is a blend of two priorities: teacher guided, and student centered. Vygotsky, the chief proponent of social constructivism argued that learning is a collaborative process between student and teacher (Dagar \& Yadav, 2016). They posit that learners do not only absorb information, but instead are actively involved in the process of knowledge acquisition through social interactions, participation and negotiation (Shah, 2019). This pedagogical approach is ideal during a pandemic, especially when students who are at home under quarantine or when a lockdown is in place and need to be supported with alternative learning plans.

The personal and personalized interface of technologies is also more conducive to the actual characteristics of distance learners and stimulate students' interests as resources are shared (Qi, 2018). It is claimed that Learning management systems (LMS) can personalize learning by encouraging teaching approaches that hold the student at the center of the learning process (Edmunds \& Hartnett, 2014). These processes allow assessment and encourage collaboration and helps students to feel more connected with teachers. However, there is little research about this form of personalized learning as LMS has not been effectively implemented in public schools in Kuwait.

\section{Strategies for creating Communities of Learning}

There is consensus that learning involves interaction and that it is a communal activity (McDaniels, Pfund \& Barnicle, 2016) The setting for communal learning activity has so far been the traditional classroom. However, with the advent of technology and the outbreak of COVID-19, that will no longer be the case. Community will be all the more important to students' engagement when virtual classrooms are used (Berry, 2017). Research suggests that synchronous hybrid virtual classrooms can help connect with remote students during synchronous teaching (Raes et al., 2020). In such virtual learning communities, all those involved have a shared goal with teachers providing academic and social support to learners and working to create a sense of belonging (Lai, 2015). In other words, learning results from practice and through interaction (Wenger, 1998).

Interaction strategies are claimed to be crucial for collaborative learning and for the collective advancement of community knowledge (Blake \& Scanlon, 2012). Heo, Lim and Kim (2010) investigated the patterns and the quality of online interaction in an undergraduate course and found that group work, presenting new information to team members and online discussions are critical for learners to generate genuine experience. According to Fatimah (2018) interaction patterns can be categorized as group work, closed-ended teacher questioning, individual work, choral responses, collaboration, student inquiry, and teacher feedback. These interaction patterns, whether dyadic or group interactions, provide learners with various opportunities for experiencing a sense of belonging and community (Zachrisen, 2016).

Teachers, who are the main point of contact for distance learning students, can play a central role by interacting with students and enabling them to foster a true sense of community in a natural way (Berry, 2019; Garrison, 2017). Although peers can better connect with students, teachers as facilitators can have a great effect on students learning (Demmans Epp, Phirangee, \& Hewitt, 2017). Phirangee, Demmans Epp, and Hewitt (2016) evaluated peer and teacher facilitation and found that students preferred teacher-facilitated online courses and engaged more in reviewing notes by making more connections with the teacher. In other words, students felt more connected when teachers played a vital role in enabling discussions. Other studies have demonstrated that the use of coursework and small group discussions where students could think deeply and share meaningful insights enabled teachers in the development of community and better engage students (Martin \& Bolliger, 2018; Garrison, 2017). However, Athens (2018) argues that collaborative activities with peers also can increase students' sense of community. Therefore, one can argue that a mix of teacher and peer facilitation can foster a true sense of community.

Literature suggests that learning in a synchronous environment has benefits for student engagement (Pinsk, Curran, Poirier, \& Coulson, 2014). The integration of synchronous tools, for example Skype, with asynchronous tools, like Twitter, blogs, and wikis, is said to have increased students' sense of community, students' sense of intimacy and immediacy in online learning environments (Abdelmalak, 2015). Clark et al., (2015) compared students' experiences with asynchronous video posts and synchronous videoconferencing to find out if it would create higher levels of teaching and social presence within an online course. The study found that social and teaching presence were significantly higher when video-based discussions were used both in synchronous and asynchronous contexts.

Lenblanc and Lindgren (2013) found that online courses with synchronous video improved communication, students' comprehension and sense of community as the virtual classrooms helped students connect with teachers. 
McDaniels et al. (2016) reported on the conversion of a face-to-face curriculum into a synchronous, online course and found that the sense of community was strong. The study revealed that there was an unexpected feeling of connection as teachers and students were frequently using online chat and discussion forums. The lack of visibility of the teacher was made up for in the level of casual sharing of course content and information. Overall, the synchronous environment was successful in creating a strong sense of community. These results corroborate the claims of Berry (2019) that a sense of community is central to student engagement and satisfaction. However, Berry (2017) claims that teachers must be skilled in using technology in ways to create a personalized learning experience.

One of the pedagogical approaches used in distance education is guided inquiry which is an innovative team approach to teaching and learning and can help learners to better understand core concepts using hands-on experimental investigations (Kam \& Hopp, 2013). The instructor guides inquiry process to allow learners gain personal perspective and an in-depth understanding through a broad range of information sources (Ajayi \& Angura, 2017). For instance, encouraging students to use search engines and personalize their search so that learners can better understand the real meaning of vague concepts, retrieve key information and ultimately improve their information-seeking behavior (Salehi, Du \& Ashman, 2018). The guided inquiry approach is generally used by teachers to enhance learning materials and channel the inquiry towards specific goals of learning (Ajayi \& Angura, 2017). It engages students in open ended, student-centered, hands on tasks while the teacher facilitates learning (Ajayi \& Angura, 2017). It is also claimed to support interaction, team building, learning and interest through highly structured group work (Trevathan \& Myers, 2013).

The knowledge generated from a review of previous literature formed the basis for constructing a theoretical framework.

\section{Theoretical framework: Community of Inquiry Framework as a Model for Social Construction of Knowledge in Distance Learning}

Flexible and personalized distance learning environments are characterized by a multitude of theoretical perspectives (Zhang et al. 2019). In the age of COVID-19 and in the context of Kuwait, there is a need to create new conceptual and theoretical frameworks to guide our understanding of the potential of distance learning contexts to connect and create communities of learning. The framework presented in this exploratory quantitative study synthesizes TPACK and the Community of Inquiry framework, and emphasizes distance teaching strategies that promote interactive teaching, cognitive and social presence.

The Community of Inquiry (COI) framework, which is a social constructivist model of learning processes in remote learning environments, consists of three interacting and overlapping presences: cognitive, social and teaching (Swan, 2019; Garrison, Cleveland-Innes \& Fung, 2010). In the model presented below (Figure 1), cognitive presence is the extent to which teachers enable learners to construct and confirm meaning in a virtual community of inquiry and maximize learning. Social presence is the ability of teachers to create a collaborative community of learners, build connections through group-work, interaction and sharing so that students can project themselves socially and emotionally. Finally, teaching presence is the design and organization of online classes, the facilitation of student-centered learning, providing feedback and using the guided inquiry process (Swan, 2019; Racheva, 2018; Garrison, Cleveland-Innes \& Fung, 2010). 


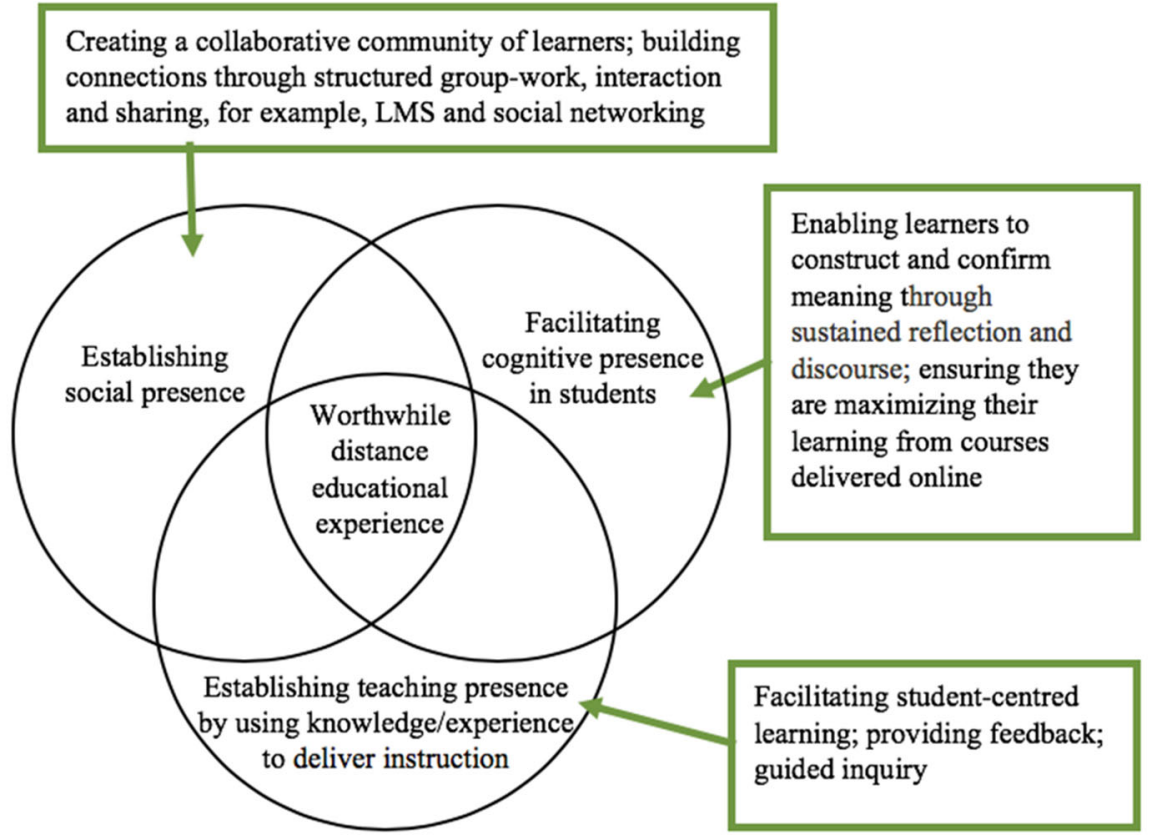

Figure 1: Connecting with students to build classroom communities using the Community of Inquiry framework (adapted from Garrison, Anderson, \& Archer, 2000 \& 2010).

The framework is claimed to be dynamic as the three presences and their elements change as distance teaching and learning courses progresses (Swan, 2019). "The model proposes that engagement in learning as well as the learner itself is the result of a well-designed and facilitated online course (teaching presence), interaction with the course content and other students focused on learning (social presence), and focused problem exploration and resolution (cognitive presence)" (Meyer, 2014, p. 17-18). It is argued that teachers can actively build and manage presence on social networks and develop personal learning environments in order to maximize the effect and authenticity of their presence (Anderson et al. 2015; Anderson \& Dron, 2012; Dron \& Anderson, 2016). Pedagogical approaches such as providing prompt feedback and discussions are claimed to support multiple presences (deNoyelles, Zydney \& Chen, 2014). In other words, these pedagogical strategies can influence more than one presence.

The COI framework was adapted and used in this study because it is suitable for implementing distance learning when students and teachers are separated due to the pandemic. Moreover, the framework is claimed to inform research and practice in and blended learning around the world (Swan, 2019). The study argues that there is the need to synthesize TPACK and COI frameworks as teachers need the skills and knowledge to use technology and adapt pedagogical approaches for distance learning. TPACK helps teachers in designing activities (collaborative design tasks) to cultivate knowledge. The main pedagogical principles of the framework presented here are student-centeredness, self-paced learning, collaboration, interaction patterns, flexibility, guided inquiry and facilitated learning. Thus, the pedagogical approach involves applying COI and social-constructive learning and situated practices. The framework presented here suggests that COI are enabled by learning management systems, collaborative platforms and social-constructivist teaching activities (Micsky \& Foels, 2019; Anderson et al. 2015; Anderson \& Dron, 2012; Dron \& Anderson, 2016; Garrison, Anderson \& Archer, 2010).

\section{Aims and research questions}

There is ongoing discussion related to the changing pedagogies across all education sectors. As technologies are becoming ubiquitous, educators need to consider the value of these tools and devices, and how to best adapt their pedagogy to make use of 'anywhere/ anytime learning' (Heggart \& Yoo, 2018). Since, new and untested technologies will be used during the lockdown to help mitigate the loss of learning, this paper argues that it is important to carefully consider how pedagogical practices need to change in order to capitalize upon these changes (Heggart \& Yoo, 2018). This requires more research on pedagogical approaches adopted by teachers to connect with students who remain isolated. However, there is a paucity of research on pedagogical approaches to delivering distance learning especially during the outbreak of a pandemics and when lockdowns are in place. Therefore, the current study attempts to conceptualize and describe teachers' pedagogical approaches to using technology for connecting with students during emergency remote instruction. It aims to provide greater understanding of what informs teachers' particular approaches and how teachers intend to change their approaches over time.

The overarching research question that guided this research was: 
- What are teachers' perceptions of connecting with students to build classroom communities during the COVID-19 pandemic?

The research question had to be answered based on the four constructs discussed in the literature review: perceived pedagogical beliefs, mode of delivery and communication, interaction patterns, and supporting community of learners through guided inquiry. This led to the development of the following sub-research questions:

1. What are the pedagogical beliefs of study participants about connecting with students in a learning environment that will be predominantly online?

2. What are the modes of delivery of instruction that the study participants had frequently used to deliver instruction and communicate with students before the switch to remote teaching?

3. Is there a difference in the study participants' interaction patterns which are significant for connecting with students to build classroom communities (a) based on teaching experience, and (b) based on specialization (subjects taught)?

4. Is there a difference in the study participants' opinions about the importance of supporting community of learners through guided inquiry: (a) based on teaching experience, and (b) based on specialization (subjects taught)?

\section{Research methodology}

Quantitative methods accentuate objective measurements and therefore this study administered a survey to teachers from various disciplines of intermediate schools in Kuwait to assess their pedagogical approaches for connecting with students to build online classroom communities in a distance learning environment. The COI and TPACK theoretical frameworks were integrated to identify the teachers' views and beliefs about their pedagogical approaches, the mode of instructional delivery, their interaction patterns, and the technology they prefer to connect, create communities of learning, guide inquiry and facilitate students' learning. Data was collected to investigate the extent to which these theoretical elements were evident in the teachers' beliefs, opinions and practices.

Survey

The questionnaire comprises of the Technological Knowledge (TK), Technological Pedagogical Knowledge (TPK), and Technological Pedagogical and Content Knowledge (TPACK) domains of the TPACK framework (Schmidt et al. 2009), the key elements of the Community of Inquiry Framework (Garrison, Anderson \& Archer, 2000), and variables from The Survey Of Technology Use In Literacy And Language Arts a validated survey developed by Hutchison and Reinking (2011), and used by Pang (2016) and Pang et al. (2015). The questionnaire consisted of four broad hypothesized strands: perceived pedagogical beliefs, mode of delivery and communication, interaction patterns, and supporting community of learners through guided inquiry. The survey items were modified from existing scales and include both generic and context-specific measures.

The survey items for perceived pedagogical beliefs measure the extent of alignment or conflict between individual teacher beliefs, practices, and actions in a remote teaching environment. It examines the extent to which teachers played a role in decision-making that affected their work. The Likert scale statements used the choices 'Strongly Disagree', 'Disagree', 'Agree', and 'Strongly Agree'. The mode of delivery and communication strand measures how teachers match learning activities with mode of delivery. The Likert scale statements used the choices 'Not at all', 'Hardly Ever', 'Not Applicable', 'Occasionally', and 'Always'. The strand on interaction patterns (teacher-student, student-student, content-student) looked at the opportunities presented by distance learning for engaging students in interactive and collaborative activities. The Likert scale statements used the choices 'Very Poorly Matched', 'Poorly Matched', 'Not Sure', 'Well Matched', And 'Very Well Matched'. The guided inquiry strand examined the extent to which teachers considered distance learning important for supporting community of learners through inquiry-based teaching and learning. The Likert scale statements used the choices 'Low Importance', 'Slightly Important', 'Neutral', 'Moderately Important', And 'Extremely Important'.

\section{Process}

The survey instrument was administered using SurveyMonkey an online survey platform. Participants accessed the SurveyMonkey website using the hyperlink sent via e-mail, WhatsApp and text messages. After they completed a consent form and consented to take part in the research, they were directed to the questionnaire (see Appendix A). There were 153 teachers who completed the survey.

\section{Reliability}

The reliability of each of the 32 items in the survey (including Teachers' self-reported pedagogical orientations) was evaluated. The alpha coefficient for the 32 items is 0.86 suggesting that the items have relatively high internal consistency.

\section{Data Analysis}

The demographic data collected included gender, age, teaching experience, subject specialization and pedagogical 
orientation. The percentage of females and males who completed the survey was $60.8 \%$ and $39 \%$ respectively. Over $61 \%$ of the teachers were in the age group of $25-35$ years while approximately $27 \%$ belonged to the $36-45$ age group. All the teachers were experienced, and their experience ranged between 0-5 years (41\%), 6-10 years $(22 \%), 11-15$ years $(17 \%), 16-20$ years $(9 \%)$ and over 20 years $(10 \%)$. The teachers' areas of specialization was diverse as they taught Islamic Study (9\%), Arabic (18\%), Mathematics (12\%), Science (6\%), English (14\%), Computer (11\%), Practical Study- electricity (16\%), Practical Study -decoration (6\%), Social sciences $(2 \%)$ and Special needs $(5 \%)$. The demographic characteristics of the participants who completed the survey indicates that the sample comprised of male and female teachers belonging to different age groups, with varied experience and diverse subject specializations.

Teachers' self-reported pedagogical orientations were traditional (11\%), a mix of traditional and constructivist approaches (33\%), a mix of traditional and some use of technology $(39 \%)$, somewhat constructivist $(17 \%)$ and highly constructivist $(0.7 \%)$. The relative frequency of the survey responses seems to suggest that the pedagogical orientations of the teachers were varying but not overtly constructivist. It was neither traditional (e.g., lectures, use of textbooks \& readings/ objective exams) nor highly constructivist for example student-generated topics, selfevaluation, independent or group research. It was a combination of traditional and constructivist orientation, for e.g., lectures, demonstrations, activities, student presentations, independent projects and exams $(32.7 \%)$ or somewhat constructivist $(17 \%)$, for example minimal lectures, more discussions, small-group activities and independent research. The teachers were inclined on combining aspects of both traditional and constructivist approaches and were willing to use technology to bridge the distance created by remote education.

\section{Results}

RQ1: What are the pedagogical beliefs of study participants about connecting with students in a learning environment that will be predominantly online?

In a review of the descriptive data (Table 1), the survey questions illustrate high levels of disagreement (Strongly Disagree, Disagree) among three of the items: (1) teaching classes that are completely online with no face-to-face class time $(\mathrm{M}=1.30 ; \mathrm{SD}=0.717) ;(2)$ only teach face to face classes that combine an online teaching experience $(\mathrm{M}=2.39 ; \mathrm{SD}=1.309)$; and (8) prefer if all courses are offered online $(\mathrm{M}=2.74 ; \mathrm{SD}=1.213)$. Although teachers were neutral in their responses to almost all the items except item 1, the results suggest that teachers were averse to teaching online and they considered face-to-face interaction with students very essential even in distance learning. However, some teachers $(\mathrm{M}=3.18 ; \mathrm{SD}=0.823)$ were willing to choose and use technology they deemed suitable as they were confident in integrating the tools $(\mathrm{M}=3.11 ; \mathrm{SD}=0.774)$, combine content, technology and pedagogy $(M=3.15 ; \mathrm{SD}=0.776)$, and because their teacher preparation programs had influenced them $(\mathrm{M}=3.05$; $\mathrm{SD}=0.864)$.

Table 1: Teachers' Pedagogical beliefs

\begin{tabular}{|c|c|c|c|}
\hline \multicolumn{2}{|c|}{ Pedagogical beliefs } & $\mathrm{M}$ & SD \\
\hline 1 & I can teach completely online with no face-to-face class time & 1.30 & 0.717 \\
\hline 2 & I can only teach face to face classes that combine an online teaching experience & 2.39 & 1.309 \\
\hline 3 & $\begin{array}{l}\text { I believe that the absence of face-to-face interaction with students is a disadvantage when } \\
\text { teaching from a distance }\end{array}$ & 3.03 & 0.996 \\
\hline 4 & $\begin{array}{l}\text { I can make decisions and choose technologies that enhance the teaching approaches for a } \\
\text { lesson }\end{array}$ & 3.18 & 0.823 \\
\hline 5 & $\begin{array}{l}\text { My teacher preparation program has caused me to think more deeply about how } \\
\text { technology could influence the teaching approaches I use for teaching online }\end{array}$ & 3.05 & 0.864 \\
\hline 6 & $\begin{array}{l}\text { I can teach lessons that appropriately combine content, technology, and teaching } \\
\text { approaches }\end{array}$ & 3.15 & 0.776 \\
\hline 7 & $\begin{array}{l}\text { I feel confident about using technology resources (such as Excel spreadsheets) to collect } \\
\text { and analyze data from student tests and products to improve instructional practices }\end{array}$ & 3.11 & 0.774 \\
\hline 8 & $\begin{array}{l}\text { I prefer if all courses associated with theoretical and practical subjects (are) offered online } \\
\text { in my school }\end{array}$ & 2.74 & 1.213 \\
\hline
\end{tabular}

RQ 2: What are the modes of delivery of instruction that the study participants had frequently used to deliver instruction and communicate with students before the switch to remote teaching?

The teachers were largely receptive to the use of various technological platforms for delivering content in a remote teaching environment. The teachers had either occasionally or always used all the ten technologies and related tools. Teachers used videos for online lecture $(\mathrm{M}=4.04 ; \mathrm{SD}=1.094)$, PowerPoint presentations for delivering content $(\mathrm{M}=4.05 ; \mathrm{SD}=1.172)$, encouraged students to use search engines $(\mathrm{M}=4.05 ; \mathrm{SD}=1.078)$ and Lecture Capture for recording classroom lectures $(\mathrm{M}=3.62 ; \mathrm{SD}=1.277)$. 
Table 2: Teachers' Preferred Mode of Instructional Delivery and Communication

\begin{tabular}{|c|c|c|c|}
\hline \multicolumn{2}{|r|}{ Mode of delivery and communication } & $\mathrm{M}$ & SD \\
\hline $\mathrm{a}$ & Learning management system (e.g., Blackboard, Canvas, Web-CT, Moodle...) & 2.96 & 1.213 \\
\hline $\mathrm{b}$ & Lecture Capture - recording, storing, and distributing videos of classroom lectures. & 3.62 & 1.277 \\
\hline $\mathrm{c}$ & Real time communication (e.g., Skype, Google Hangout, WhatsApp) & 3.61 & 1.377 \\
\hline $\mathrm{d}$ & Delayed discussion (e.g., Discussion board, email ...) & 3.40 & 1.397 \\
\hline $\mathrm{e}$ & Video (e.g., YouTube, Vimeo...) & 4.04 & 1.094 \\
\hline $\mathrm{f}$ & PowerPoint Presentations & 4.05 & 1.172 \\
\hline $\mathrm{g}$ & Online quizzes & 3.67 & 1.312 \\
\hline $\mathrm{h}$ & Web searching (e.g., Google, Bing, Yahoo...) & 4.05 & 1.078 \\
\hline $\mathrm{i}$ & Social networking (e.g., Facebook, Twitter...) & 3.68 & 1.321 \\
\hline $\mathrm{j}$ & $\mathrm{B} \log \mathrm{s}$ & 3.41 & 1.416 \\
\hline
\end{tabular}

They connected with students using real time communication tools $(\mathrm{M}=3.61 ; \mathrm{SD}=1.377)$, discussion boards and emails $(\mathrm{M}=3.40 ; \mathrm{SD}=1.397)$ and social networking platforms $(\mathrm{M}=3.68 ; \mathrm{SD}=1.321)$. What was surprising was that Learning Management Systems were not commonly used by the teachers $(\mathrm{M}=2.96 ; \mathrm{SD}=1.213)$.

RQ3: Is there a difference in the study participants' interaction patterns which are significant for connecting with students to build classroom communities (a) based on teaching experience, and (b) based on specialization (subjects taught)?

The descriptive data indicates that the teachers were not aware of the interaction patterns which is evident in the high percentage of 'not sure' responses (Table 3). The data also demonstrates that the teachers considered all the six interaction patterns to be either 'very poorly matched' or 'poorly matched'.

Table 3: Interaction patterns

\begin{tabular}{|l|l|l|l|}
\hline \multicolumn{2}{|l|}{ Interaction patterns } & M & SD \\
\hline $\mathrm{a}$ & Modeling & 2.59 & 0.738 \\
\hline $\mathrm{b}$ & Discussion & 2.56 & 0.733 \\
\hline $\mathrm{c}$ & Presenting ideas, concepts, principles & 2.55 & 0.777 \\
\hline $\mathrm{d}$ & Dealing with assignments & 2.57 & 0.817 \\
\hline e & Researching topics & 2.58 & 0.767 \\
\hline f & Group work & 2.52 & 0.867 \\
\hline
\end{tabular}

One-way ANOVA was used to compare means between demographic subgroups (teachers based on their experience and specialization) to establish if differences existed.

The hypotheses tested for the subgroup 'experience' were:

Hypothesis H1. There is a significant difference in participants' opinions on interaction patterns based on their experience

Hypothesis Ho1. There is no significant difference in participants' opinions on interaction patterns based on their experience

The variables for Tables 4 and 5 are: (a) Modeling; (b) Discussion; (c) Presenting ideas, concepts, etc.; (d) Dealing with assignments; (e) Researching topics; and (f) Group work.

Table 4: Interaction patterns based on teachers' experience

\begin{tabular}{|l|l|l|l|l|l|l|}
\hline \multicolumn{2}{|l|}{ Interaction patterns based on teachers' experience } \\
\hline Variable & Source of Variation & SS & df & MS & F & P-value \\
\hline \multirow{3}{*}{ a } & Between Groups & 1.52 & 4 & 0.38 & 0.6914 & 0.5990 \\
\cline { 2 - 7 } & Within Groups & 81.36 & 148 & 0.55 & & \\
\hline b & Between Groups & 2.71 & 4 & 0.68 & 1.2683 & 0.2851 \\
\cline { 2 - 7 } & Within Groups & 78.95 & 148 & 0.53 & & \\
\hline c & Between Groups & 2.75 & 4 & 0.69 & 1.1434 & 0.3385 \\
\cline { 2 - 7 } & Within Groups & 89.13 & 148 & 0.60 & & \\
\hline \multirow{2}{*}{ d } & Between Groups & 2.61 & 4 & 0.65 & 0.9765 & 0.4223 \\
\cline { 2 - 7 } & Within Groups & 98.92 & 148 & 0.67 & & \\
\hline \multirow{2}{*}{ e } & Between Groups & 2.60 & 4 & 0.65 & 1.1094 & 0.3543 \\
\cline { 2 - 7 } & Within Groups & 86.783 & 148 & 0.58 & & \\
\cline { 2 - 7 } & Between Groups & 0.228 & 4 & 0.06 & 0.074 & 0.9900 \\
\cline { 2 - 7 } & Within Groups & 113.981 & 148 & 0.77 & & \\
\hline
\end{tabular}

The results (Table 5) suggest there were no statistically significant differences between groups as determined by one-way ANOVA for all the six variables $(p=>.05)$. The $p$-values are greater than the significance level, and therefore there is not enough evidence to reject the null hypothesis (Ho1).

The hypotheses tested for the subgroup 'specialization' were: 
Hypothesis H2. There is a significant difference in the participants' opinions on interaction patterns based on courses they taught.

Hypothesis Ho2. There is no significant difference in the participants' opinions on interaction patterns based on courses they taught.

Table 5: Interaction patterns based on teachers' specialization

\begin{tabular}{|c|c|c|c|c|c|c|}
\hline \multicolumn{7}{|c|}{ Interaction patterns based on teachers' specialization } \\
\hline Variable & Source of Variation & SS & $\mathrm{df}$ & MS & $\mathrm{F}$ & P-value \\
\hline \multirow[t]{2}{*}{$\mathrm{a}$} & Between Groups & 4.44 & 9 & 0.494 & 0.9015 & 0.525 \\
\hline & Within Groups & 78.42 & 143 & 0.548 & & \\
\hline \multirow[t]{2}{*}{ b } & Between Groups & 5.86 & 9 & 0.651 & 1.2292 & 0.281 \\
\hline & Within Groups & 75.79 & 143 & 0.530 & & \\
\hline \multirow[t]{2}{*}{$\mathrm{c}$} & Between Groups & 4.51 & 9 & 0.500 & 0.8199 & 0.598 \\
\hline & Within Groups & 87.37 & 143 & 0.611 & & \\
\hline \multirow[t]{2}{*}{$\mathrm{d}$} & Between Groups & 8.88 & 9 & 0.986 & 1.5231 & 0.145 \\
\hline & Within Groups & 92.64 & 143 & 0.647 & & \\
\hline \multirow[t]{2}{*}{ e } & Between Groups & 8.26 & 9 & 0.918 & 1.6193 & 0.114 \\
\hline & Within Groups & 81.12 & 143 & 0.567 & & \\
\hline \multirow[t]{2}{*}{$f$} & Between Groups & 8.18 & 9 & 0.908 & 1.2252 & 0.284 \\
\hline & Within Groups & 106.03 & 143 & 0.741 & & \\
\hline
\end{tabular}

The ANOVA results (Table 5) indicated that there are no statistically significant differences between groups and within groups for all the variables $(\mathrm{p}=>.05)$. This indicates strong evidence for the null hypothesis (Ho2) that there is no significant difference in the participants' opinions on interaction patterns based on courses they taught.

RQ4: Is there a difference in the study participants' opinions about the importance of supporting community of learners through guided inquiry: (a) based on teaching experience, and (b) based on specialization (subjects taught)? The descriptive statistics suggest that the teachers were not embedding inquiry-based learning activities (Table 6). The teachers did not give importance to structuring courses or learning activities, discussion forums or providing feedback.

Table 6: Guided inquiry

\begin{tabular}{|l|l|l|}
\hline Guided inquiry & M & SD \\
\hline a. Structuring courses for best online experience & 1.67 & 0.999 \\
\hline b. Using discussion forums effectively & 2.01 & 1.186 \\
\hline c. Structuring learning activities to foster student-faculty interaction & 1.64 & 0.964 \\
\hline d. Structuring learning activities that foster student-student interaction & 1.67 & 0.972 \\
\hline e. Structuring learning activities that foster student-content interaction & 1.63 & 0.952 \\
\hline f. Giving students constructive feedback in a timely manner & 1.62 & 0.932 \\
\hline g. Gathering feedback from students to improve the learning experience & 1.66 & 1.001 \\
\hline
\end{tabular}

Guided inquiry was evaluated for differences based on teachers' experience and specialization.

The hypotheses tested for the subgroup 'experience' were:

Hypothesis H3. There is a significant difference in participants' perceptions of distance learning in supporting community of learners through guided inquiry based on their experience.

Hypothesis Ho3. There is no significant difference in participants' perceptions of distance learning in supporting community of learners through guided inquiry based on their experience.

Table 7: Guided inquiry based on teachers' experience

\begin{tabular}{|c|c|c|c|c|c|c|}
\hline \multicolumn{7}{|l|}{ Guided inquiry based on teachers' experience } \\
\hline Variable & $\begin{array}{l}\text { Source of } \\
\text { Variation }\end{array}$ & $\mathrm{SS}$ & df & MS & $\mathrm{F}$ & P-value \\
\hline \multirow{2}{*}{$\begin{array}{l}\text { a. Structuring courses for best online } \\
\text { experience }\end{array}$} & Between Groups & 6.80 & 4 & 1.70 & 1.7373 & 0.1448 \\
\hline & Within Groups & 144.86 & 148 & 0.97 & & \\
\hline \multirow{2}{*}{ b. Using discussion forums effectively } & Between Groups & 8.08 & 4 & 2.02 & 1.4524 & 0.2197 \\
\hline & Within Groups & 205.89 & 148 & 1.39 & & \\
\hline \multirow{2}{*}{$\begin{array}{l}\text { c. Structuring learning activities to foster } \\
\text { student-faculty interaction }\end{array}$} & Between Groups & 5.80 & 4 & 1.45 & 1.5832 & 0.1817 \\
\hline & Within Groups & 135.43 & 148 & 0.91 & & \\
\hline \multirow{2}{*}{$\begin{array}{l}\text { d. Structuring learning activities that foster } \\
\text { student-student interaction }\end{array}$} & Between Groups & 4.46 & 4 & 1.11 & 1.1854 & 0.3197 \\
\hline & Within Groups & 139.2 & 148 & 0.94 & & \\
\hline \multirow{2}{*}{$\begin{array}{l}\text { e. Structuring learning activities that foster } \\
\text { student-content interaction }\end{array}$} & Between Groups & 4.25 & 4 & 1.06 & 1.1776 & 0.3231 \\
\hline & Within Groups & 133.52 & 148 & 0.90 & & \\
\hline
\end{tabular}




\begin{tabular}{|c|c|c|c|c|c|c|}
\hline \multicolumn{7}{|l|}{ Guided inquiry based on teachers' experience } \\
\hline Variable & $\begin{array}{l}\text { Source of } \\
\text { Variation }\end{array}$ & SS & df & MS & $\mathrm{F}$ & P-value \\
\hline \multirow{2}{*}{$\begin{array}{l}\text { f. Giving students constructive feedback in a } \\
\text { timely manner }\end{array}$} & Between Groups & 3.05 & 4 & 0.76 & 0.8755 & 0.4802 \\
\hline & Within Groups & 128.96 & 148 & 0.87 & & \\
\hline \multirow{2}{*}{$\begin{array}{l}\text { g. Gathering feedback from students to } \\
\text { improve the learning experience }\end{array}$} & Between Groups & 5.52 & 4 & 1.38 & 1.3918 & 0.2396 \\
\hline & Within Groups & 146.80 & 148 & 0.99 & & \\
\hline
\end{tabular}

The ANOVA results (Table 7) indicated that there are no statistically significant differences between groups and within groups for all the variables $(\mathrm{p}=>.05)$. The results provide support for retaining the null hypothesis and rejecting the alternative hypothesis.

The hypotheses tested for the subgroup 'specialization' were:

Hypothesis H4. There is a significant difference in participants' perceptions of distance learning in supporting community of learners through guided inquiry based on courses they taught.

Hypothesis Ho4. There is no significant difference in participants' perceptions of distance learning in supporting community of learners through guided inquiry based on courses they taught.

Table 8: Guided inquiry based on teachers' specialization

\begin{tabular}{|c|c|c|c|c|c|c|c|}
\hline \multicolumn{8}{|c|}{ Guided inquiry based on teachers' specialization } \\
\hline Variable & Source of Variation & $\mathrm{SS}$ & df & MS & $\mathrm{F}$ & P-value & Tukey HSD (alpha=.05) \\
\hline \multirow[t]{2}{*}{$\bar{a}$} & Between Groups & 16.44 & 9 & 1.83 & 1.9318 & 0.05189 & \\
\hline & Within Groups & 135.22 & 143 & 0.95 & & & \\
\hline \multirow[t]{2}{*}{ b } & Between Groups & 29.10 & 9 & 3.23 & 2.5013 & 0.01095 & \multirow{2}{*}{$\begin{array}{l}\text { Between Groups } 5 \& 8=1.5 \\
(p=0.0353)\end{array}$} \\
\hline & Within Groups & 184.87 & 143 & 1.29 & & & \\
\hline \multirow[t]{2}{*}{$\mathrm{c}$} & Between Groups & 8.86 & 9 & 0.98 & 1.0634 & 0.39351 & \\
\hline & Within Groups & 132.37 & 143 & 0.93 & & & \\
\hline \multirow[t]{2}{*}{$\mathrm{d}$} & Between Groups & 12.26 & 9 & 1.36 & 1.4827 & 0.15966 & \\
\hline & Within Groups & 131.40 & 143 & 0.93 & & & \\
\hline \multirow[t]{2}{*}{$\mathrm{e}$} & Between Groups & 15.23 & 9 & 1.69 & 1.9746 & 0.04635 & \multirow{2}{*}{$\begin{array}{l}\text { Between Groups } 4 \& 8=1.4444 \\
(p=0.0379)\end{array}$} \\
\hline & Within Groups & 122.54 & 143 & 0.86 & & & \\
\hline \multirow[t]{2}{*}{$\mathrm{f}$} & Between Groups & 14.61 & 9 & 1.62 & 1.977 & 0.04606 & \multirow{2}{*}{$\begin{array}{l}\text { No significant difference } \\
\text { between any two groups }\end{array}$} \\
\hline & Within Groups & 117.40 & 143 & 0.82 & & & \\
\hline \multirow[t]{2}{*}{$\mathrm{g}$} & Between Groups & 13.08 & 9 & 1.45 & 1.4928 & 0.15589 & \\
\hline & Within Groups & 139.24 & 143 & 0.97 & & & \\
\hline
\end{tabular}

The ANOVA results indicated that there are no statistically significant differences between groups and within groups for most variables (items a, c, d and g). However, there were significant differences for three scales, namely (b) using discussion forums effectively: $F=2.5013, p<.05$; (e) structuring learning activities that foster studentcontent interaction: $\mathrm{F}=1.9746, \mathrm{p}<.05$; and (f) giving students constructive feedback in a timely manner: $\mathrm{F}=1.977$, $\mathrm{p}<.05)$. Results indicate that significant differences occurred among the groups for these three variables, but do not indicate which groups account for the significance. To find the differences between the groups, the post-hoc Tukey HSD test was performed on the data for guided inquiry based on teachers' specialization. The Tukey tests indicated that the differences existed between Group 5 and Group $8=1.5(\mathrm{p}=0.0353)$ and between Group 4 and Group $8=1.4444(p=0.0379)$. However, the test confirmed the ANOVA results for variable (f) that there is no significant difference between any two groups. As $\mathrm{p}<0.05$, the null hypothesis (Ho4) that there is no significant difference in participants' perceptions of distance learning in supporting community of learners through guided inquiry based on their specialization was rejected.

\section{Discussion}

The findings suggest that changing the pedagogical practices of teachers from transmission to full integration of technology is not as straightforward as it may appear as reported previously (Tarling and Ng'ambi, 2016). The teachers do not have constructivist-oriented pedagogical beliefs and therefore do not focus on personalization. The results contradict previous reports (for example Qi, 2017; Salehi, Du \& Ashman, 2018) that personalized instruction is key in distance education contexts. As noted earlier, the community of enquiry (COI) is a social constructivist model and therefore not readily compatible with technology enabled learning that is completely individualized (Anderson, 2017).

The absence of the face-to-face interaction with their students in distance education proved to be a factor of instability for the teachers in this study. This validates the results reported by Carmo and Franco (2019) who claim that the the pedagogical mediation in a virtual or remote learning environment is a challenge because of the loss 
of the body language elements in interaction mediated by technology.

Another finding was that the pedagogies required for the effective implementation of remote learning were not yet in evidence amongst the majority of teachers. Although the teachers were aware of the mode of delivery and communication, their focus was not on the content, delivery and coordination of the learning environment as should be the case and as suggested in literature (Garrison, Baia, Canning \& Strang, 2015; Mishra \& Koehler, 2006). The teachers were willing to integrate synchronous tools, such as Skype, with asynchronous tools, like Twitter, blogs, and wikis. They used real time communication tools to enhance the interaction. This indicates that the teachers were keen on increasing students' sense of community. The intention to use various modes of communication demonstrates that the teachers considered them important for connecting with students to build classroom communities (Yamagata-Lynch, 2018; Abdelmalak, 2015; Clark, Strudler \& Grove, 2015). From these results, it appears that the teachers were aware of the significance of technology and social presence which are crucial in creating a community of inquiry (Garrison, 2017). The teachers had encouraged students to use search engines in order to enhance the experience- information-seeking behavior of university students. This corroborates the findings of Salehi et al. (2018). Overall, it is evident that there will be a continuum of technology-based instruction when the teachers transition from face-to-face teaching to fully online remote teaching.

One of the unique findings was that although remote learning is associated with the lack of physical contact and social isolation teachers were not aware of the interaction patterns, both dyadic and group interactions. This is evident from the descriptive statistics which suggest that none of the interaction patterns matched with their pedagogical orientation. ANOVA results also indicate that there are no statistically significant differences between groups. This contrasts with findings reported in literature that interaction patterns are key for enabling students to experience a sense of belonging and community (Zachrisen, 2016). Interactions in remote education requires the knowledge of navigating through various technological and pedagogical tools (Carmo \& Franco, 2019), but the teachers in this study lacked the technological competence of an online tutor. Although teachers considered social media and technology as essential tools for building social presence and creating a community of inquiry, they were not aware of student interactions in distance education contexts, and did not understand the significance of these events in developing students' sense of community (Berry, 2017; Berry, 2019). The results also indicate that the teachers were unable to "balance interaction," build "group cohesion" and facilitate and "model critical discourse" which are "essential for productive inquiry" (Garrison, 2017, p. 7).

The descriptive data and the results of ANOVA and Tukey indicate that most teachers irrespective of their subject specializations or experience did not consider structuring courses, lessons and learning activities or giving feedback to students to be important for distance education in the context of the current pandemic. The results suggest that the teachers were not embedding inquiry-based learning activities. Contrary to what literature suggests, the teachers appeared to not enhance students learning by channeling the inquiry towards specific goals of learning (Ajayi \& Angura, 2017), for instance by supporting interaction, altering the structure of teaching activities to create opportunities for social interaction through group work (Berry, 2019; Trevathan \& Myers, 2013). It is interesting to note that although the teachers used social media to increase interactions and build social presence, they did not believe that distance learning allows for immediate feedback in the form of just-in-time clarification (Racheva, 2018).

\section{Limitations}

This study was conducted only in selected public intermediate schools in Kuwait. A sample with broader representation of teachers from public and private intermediate schools would strengthen the transferability of the results. The findings in the present study are limited to the particular research context and participants. Furthermore, the results in the study were based on the self-reports of teachers and there was limited knowledge of how they conceptualized the issues investigated.

\section{Implications}

The findings have implications for policy makers and suggests that teacher education needs to address pandemicforced school closures by training teachers to not only deliver instruction from a distance but carry out their teaching activities when students and teachers are socially isolated.

Training is needed so that teachers can identify specific pedagogical approaches for cultivating learning communities online. Training programs are required to guide all teachers to be reflective, not only on how they approach remote teaching, but also concerning how their approaches to teaching influence the way their students approach learning. Pedagogical training could be organized for them to develop strategies for remote teaching by balancing the three presences described in COI.

Teachers must respond to challenges by transforming these challenging situations into opportunities and strategically reduce their expectations for all students and identify a few specific areas they want students to focus on. The results can help teachers to address adversity, and support resilience.

The study provides new insights into research on teachers' approaches to teaching during a pandemic, which 
is scarce. However, more evidence is needed to enrich knowledge in this area. There is the need to provide an indepth understanding of pedagogical approaches to connect with students during an emergency and therefore interviews and qualitative analyses could be added.

\section{Disclosure statement}

The researchers report no potential conflict of interest.

\section{Compliance with Ethical Standards}

This research involves human participants and all procedures performed in this study were in accordance with universal ethical standards and with the 1964 Helsinki declaration and its later amendments or comparable ethical standards. The authors declare that the data collection, processing and analysis meets those ethical requirements. Informed consent

Informed consent was obtained from all research participants prior to their participation. They were informed that their participation was voluntary and that they had the freedom to withdraw at any time, without giving a reason and without cost.

\section{Disclosure of potential conflicts of interest}

The authors declare that: no support, financial or otherwise, has been received from anyone that may have an interest in the submitted work; and there are no other relationships or activities that could appear to have influenced the submitted work.

\section{References}

Abdelmalak, M. M. M. (2015). Web 2.0 technologies and building online learning communities: Students' perspectives. Online Learning, 19(2). [Online] https://eric.ed.gov/?id=EJ1062942 (Accessed 8 May 2020).

Abiad, A., Arao, M., Dagli, D., Ferrarini, B....et al. (2020) The Economic Impact of the COVID-19 Outbreak on Developing Asia, Asian Development Bank Brief No. 28 DOI: DOI: 10.22617/BRF200096

Ajayi, V., \& Angura, M, (2017). Do Guided and Structured Inquiry Instructional Strategies Have Any Comparative Effects on Students' Achievement in Basic Science and Technology? A Field Report. Journal of Education and Practice. 8(33), 81-88 DOI:10.2139/ssrn.3069288.

Al-Awidi, H., \& Aldhafeeri, F. (2017). Teachers' readiness to implement digital curriculum in Kuwaiti schools. Journal of Information Technology Education Research, 16(1), 105-126.

Alenezi, E. G. (2018) An investigation of teacher's beliefs and attitudes regarding the use of tablet computers as a pedagogical tool in teaching practical studies (Electricity and Electronics) in Kuwait Intermediate Schools. Doctoral thesis University of Southampton, Doctoral Thesis, pp. 320.

Alfelaij, B. (2016). Why integrating technology has been unsuccessful in Kuwait? An exploratory study. ELearning and Digital Media, 13(3-4), 126-139.

Almodaires, A., Alayyar, G., Almsaud, T., \& Almutairi, F. (2019). The Effectiveness of Flipped Learning: A Quasi-Experimental Study of the Perceptions of Kuwaiti Pre-Service Teachers. International Education Studies. International Education Studies, 12(1), DOI:10.5539/ies.v12n1p10

Anderson, T. (2017). How Communities of Inquiry Drive Teaching and Learning in the Digital Age, Contact North. [Online] https://teachonline.ca/tools-trends/insights-online-learning/2018-02-27/how-communities-inquirydrive-teaching-and-learning-digital-age (Accessed 18 May 2020).

Anderson, T., Upton, L., Dron, J., Malone, J., \& Poelhuner, B. (2015). Social interaction in self-paced distance education. Open Praxis, 7(1), 7-23.

Anderson, T., \& Dron, J. (2012). Learning technology through three generations of technology enhanced distance education pedagogy. European Journal of Open, Distance and E-Learning, (2) [Online] https://files.eric.ed.gov/fulltext/EJ992485.pdf (Accessed 18 May 2020).

Athens, W. (2018). Perceptions of the persistent: Engagement and learning community in underrepresented populations. Online Learning, 22(2), 27-58. DOI: 10.24059/olj.v22i2.1368

Bansal G., Ramnarain U., Schuster D. (2019) Examining Pre-service Science Teachers Pedagogical Orientations in an Era of Change in India. In: Koul R., Verma G., Nargund-Joshi V. (eds) Science Education in India. Springer, Singapore DOI:10.1007/978-981-13-9593-2_4

Bates, T. (2020). Advice to those about to teach online because of the coronavirus [Online] https://www.tonybates.ca/2020/03/09/advice-to-those-about-to-teach-online-because-of-the-coronavirus (Accessed 13 May 2020).

Berry, S. (2017). Building community in online doctoral classrooms: Instructor practices that support community. Online Learning, 21(2). DOI:10.24059/olj.v21i2.875

Berry, S. (2019). Teaching to connect: Community-building strategies for the virtual classroom. Online Learning, 23(1), 164-183. DOI:10.24059/olj.v23i1.1425 
Blake, C., \& Scanlon, E. (2012) Analysing Collaborative Processes and Interaction Patterns in Online Discussions. Proceedings of the 8th International Conference on Networked Learning, Hodgson. V., Jones. C., de Laat. M., McConnell. D., Ryberg. T., \& Sloep. P. (Eds) pp.10-17. April, 2-4, 2012, Maastricht, The Netherlands.

Burgess, S., \& Sievertsen, H.H. (2020) Schools, skills, and learning: The impact of COVID-19 on education, VOX CEPR Policy Portal, 1st April 2020, [Online] https://voxeu.org/article/impact-covid-19-education(Accessed 13 May 2020).

Burke, P. F., Schuck, S., Aubusson, P., Kearney, M., \& Frischknecht, B. (2018) Exploring teacher pedagogy, stages of concern and accessibility as determinants of technology adoption, Technology, Pedagogy and Education, 27(2), 149-163, DOI:10.1080/1475939X.2017.1387602

Carmo, R.O.S., \& Franco, A.P. (2019) From Face-To-Face Teaching To Online Teaching: The Learning Of University Teachers In Distance Education Educação em Revista, 35, e210399. DOI:10.1590/01024698210399.

Cassidy, A., Fu, G., Valley, W., Lomas, C., Jovel, E., \& Riseman, A. (2016). Flexible Learning Strategies in First through Fourth-Year Courses. Collected Essays on Learning and Teaching. 9.83. DOI:10.22329/celt.v9i0.4438.

Clark, C., Strudler, N., \& Grove, K. (2015). Comparing asynchronous and synchronous video vs.text-based discussions in an online teacher education course. Online Learning, 19(3), 48-69.

Dada, E.G., Alkali, A.H., \& Oyewola, D.O. (2019) An Investigation into the Effectiveness of Asynchronous and Synchronous E-learning Mode on Students' Academic Performance in National Open University (NOUN), Maiduguri Centre International Journal of Modern Education and Computer Science 11 (5), 54-64.

Dagar V, Yadav A (2016) Constructivism: A Paradigm for Teaching and Learning. Arts and Social Sciences Journal 7: 200. DOI:10.4172/2151-6200.1000200

Demmans Epp, C., Phirangee, K., \& Hewitt, J. (2017). Student actions and community in online courses: The roles played by course length and facilitation method. Online Learning, 21(4), 53-77. DOI: $10.24059 /$ olj.v21i4.1269

deNoyelles, A., Zydney, J.M., \& Chen, B. (2014). Strategies for Creating a Community of Inquiry through Online Asynchronous Discussions, MERLOT Journal of Online Learning and Teaching, 10(1), 153-165.

Dron, J., \& Anderson, T. (2016). The future of e-learning. In C. Haythornthwaite, R. Andrews, J. Fransman \& E. Meyers (Eds.), The Sage handbook of e-learning research, pp. 537- 556, London, UK: Sage.

Edmunds, B., \& Hartnett, M. (2014) Using a learning management system to personalise learning for primary school students, Journal of Open, Flexible, and Distance Learning, 18(1), 11-29.

EPALE(2020) COVID-19 is reviving the need to explore online teaching and learning opportunities, EPALE Electronic Platform for Adult Learning in Europe, European Commission [Online] https://epale.ec.europa.eu/en/blog/covid-19-reviving-need-explore-online-teaching-and-learningopportunities(Accessed 22 May 2020).

Fatimah, S. (2018). Patterns of Teaching-Learning Interaction in the EFL Classroom. Teknosastik 16 (2), 41-48. DOI: $10.33365 /$ ts.v16i2.139.

Garrison, D. R. (2017). E-Learning in the 21st Century: A Community of Inquiry Framework for Research and Practice (3rd Edition). London: Routledge/Taylor and Francis.

Garrison, D. R., Anderson, T., \& Archer, W. (2000). Critical inquiry in a text-based environment: Computer conferencing in higher education. Internet and Higher Education, 2(2-3), 87-105

Garrison, D. R., Anderson, T., \& Archer, W. (2010). The first decade of the community of inquiry framework: A retrospective. The Internet and Higher Education, 13(1), 5-9.

Garrison, D. R., Cleveland-Innes, M., \& Fung, T. S. (2010). Exploring causal relationships among teaching, cognitive and social presence: Student perceptions of the community of inquiry framework. Internet and Higher Education, 13, 31-36. DOI:10.1016/j.iheduc.2009.10.002

Garrison, G. D., Baia, P., Canning, J. E., \& Strang, A. F. (2015). An asynchronous learning approach for the instructional component of a dual-campus pharmacy resident teaching program. American journal of pharmaceutical education, 79(2), 29. DOI:10.5688/ajpe79229

Guilar, J. \& Loring, A. (2008). Dialogue and Community in Online Learning: Lessons From Royal Roads University. Journal of Distance Education Revue de L'Education à distance 22(3), 19-40.

Heggart, K.R., \& Yoo, J. (2018) Getting the Most from Google Classroom: A Pedagogical Framework for Tertiary Educators Australian Journal of Teacher Education 43(3) 140-153 DOI: 10.14221/ajte.2018v43n3.9

Heo, H., Lim, K.Y., Kim, Y. (2010) Exploratory study on the patterns of online interaction and knowledge coconstruction in project-based learning. Computers \& Education 55(3), 1383-1392.

Hutchison, A., \& Reinking, D. (2011) A national survey of barriers to integrating information and communication technologies into literacy instruction, In Proceedings of the 59th yearbook of the National Reading Conference, R. Jimenez, V. Risko, M. Hundley, and D. Rowe, Eds., pp. 230-243, Milwaukee, Wis, USA, 2010. 
Kam, R., \& Hopp, B. (2013) Facilitating Inquiry-Based Science Learning Online in a Virtual University Higher Learning Research Communications 3(2), 79-81.

Lai, K. W. (2015). Knowledge construction in online learning communities: A case study of a doctoral course. Studies in Higher Education, 40(4), 561-579.

Leblanc, A., \& Lindgren, C. (2013). Development of on-line courses focusing on quality. In: Open and Flexible Higher Education Conference, 23-25 Oct 2013, Paris, France, European Association of Distance Teaching Universities (EADTU), pp. 220-228.

Martin, F., \& Bolliger, D. U. (2018). Engagement matters: Student perceptions on the importance of engagement strategies in the online learning environment. Online Learning, 22(1). [Online] https://olj.onlinelearningconsortium.org/index.php/olj/article/view/1092/371(Accessed 18 May 2020).

McDaniels, M., Pfund, C., \& Barnicle, K. (2016). Creating dynamic learning communities in synchronous online courses: One approach from the Center for the Integration of Research, Teaching and Learning (CIRTL). Online Learning, 20(1), 110-129. DOI: 10.24059/olj.v20i1.518

Meyer, K. A. (2014). Student engagement online: What works and why (ASHE Higher Education Report). San Francisco, CA: Jossey-Bass.

Micsky, T., \& Foels, L. (2019) Community of Inquiry (COI): A Framework for Social Work Distance Educators, Journal of Teaching in Social Work, 39:4-5, 293-307, DOI:10.1080/08841233.2019.1642976

Mishra, P., \& Koehler, M.J. (2006) Technological Pedagogical Content Knowledge: A Framework for Teacher Knowledge, Teachers' College Record, 108(6), 1017-1054.

Naidu, S. (2017). Openness and flexibility are the norm, but what are the challenges? Distance Education, 38, 14. DOI:10.1080/01587919.2017.1297185

Pang, S. (2016). A National Survey of Literacy Faculty Practices, Beliefs, and Attitudes Toward Online Courses. All Dissertations. 1710. Clemson University [Online] https://tigerprints.clemson.edu/all_dissertations/1710

Pang, S., Reinking, D., Hutchison, A., \& Ramey, D. (2015) South Korean teachers' perceptions of integrating information and communication technologies into literacy instruction Education Research International Article ID 783593 DOI:10.1155/2015/783593

Phirangee, K., Demmans Epp, C., \& Hewitt, J. (2016b). Exploring the relationships between facilitation methods, students' sense of community and their online behaviours. Online Learning Journal, 20(2). DOI: 10.24059/olj.v20i2.775

Pinsk, R., Curran, M., Poirier, R., \& Coulson, G. (2014). Student perceptions of the use of student-generated video in online discussions as a mechanism to establish social presence for non-traditional students: A case study. Issues in Information Systems, 15, 267-276.

Prestridge, S. (2017) Examining the shaping of teachers' pedagogical orientation for the use of technology, Technology, Pedagogy and Education, 26(4), 367-381, DOI: 10.1080/1475939X.2016.1258369

Qi, Z. (2018). Personalized Distance Education System Based on Data Mining, International Journal of Emerging Technologies in Learning, 13(7), 4-16 DOI:10.3991/ijet.v13i07.8810

Racheva, V. (2018). Social Aspects of Synchronous Virtual Learning Environments AIP Conference Proceedings 2048, 020032, 8-13 June 2018, Sozopol, Bulgaria. DOI: 10.1063/1.5082050

Raes, A., Detienne, L., Windey, I., \& Depaepe, F. (2019). A Systematic Literature Review On Synchronous Hybrid Learning: Gaps Identified. Learning Environments Research; 1 - 22 Learning Environments Research DOI:10.1007/s10984-019-09303-z

Raes, A., Vanneste, P., Pieters, M., Windey, I., Van Den, N., \& Depaepe, F. (2020). Learning and instruction in the hybrid virtual classroom: An investigation of students' engagement and the effect of quizzes. Computers \& Education; 143(2020),1-16. DOI: 10.1016/j.compedu.2019.103682G

Roulston, S., Cowan, P., Brown, M., Austin, R., \& O'Hara, J. (2019). All aboard or still at check-in? Teacher educators' use of digital technologies: Lessons from a small island. Education and Information Technologies, 24(6), 3785-3802. DOI:10.1007/s10639-019-09951-x

Salehi, S., Du, J.T. \& Ashman, H. (2018). Use of Web search engines and personalisation in information searching for educational purposes. Information Research, 23(2), paper 788. [Online] http://InformationR.net/ir/232/paper788.html (Accessed 25 May 2020).

Schmidt, D. A., Baran, E., Thompson, A. D., Mishra, P., Koehler, M. J., \& Shin, T. S. (2009). Technological pedagogical content knowledge (TPACK): The Development and validation of an assessment instrument for preservice teachers. Journal of Research on Technology in Education, 42(2), 123-149.

Shah, R. K. (2019). Effective social constructivist approach to learning for social studies classroom. Journal of Pedagogical Research, 3(2), 38-51. DOI:10.33902/JPR.2019254159

Swan, K. (2019). Social Construction of Knowledge and the Community of Inquiry Framework. DOI: 10.1007/978-981-13-7740-2 7

Tarling, I., \& Ng'ambi, D. (2016) Teachers pedagogical change framework: a diagnostic tool for changing teachers' uses of emerging technologies British Journal of Educational Technology 47(3), 554-572 
DOI:10.1111/bjet.12454

Tomei, L.A. (2010). Lexicon of Online and Distance Learning. Lanham, MD: Rowan \& Littlefield Education.

Trevathan, J. \& Myers, T. (2013). Towards Online Delivery of Process-Oriented Guided Inquiry Learning Techniques in Information Technology Courses. Journal of Learning Design, 6(2), 1-11.

Wenger, E. (1998). Communities of practice: Learning, meaning, and identity. Cambridge University Press. https:// https://doi.org/10.1017/CBO9780511803932

World Bank (2020) The World Bank Education Global Practice Guidance Note: Remote Learning \& COVID-19. 7th April 2020 [Online] http://documents.worldbank.org/curated/en/531681585957264427/pdf/GuidanceNote-on-Remote-Learning-and-COVID-19.pdf (Accessed 2 May 2020).

Yamagata-Lynch, L. C. (2018). Blending online asynchronous and synchronous learning, Demonstration Journal $\begin{array}{lllll}\text { of the Classic } & \text { Theme, } & 1(3) . & \end{array}$ https://demo.publicknowledgeproject.org/ojs3/demo/index.php/classic/article/view/828 (Accessed 4 May 2020).

Zachrisen, B. (2016). The contribution of different patterns of teachers' interactions to young children's experiences of democratic values during play. International Journal of Early Childhood 48, 179-192.

Zhang, J., Burgos, D., \& Dawson, S. (2019) Advancing open, flexible and distance learning through learning analytics, Distance Education, 40(3), 303-308, DOI: 10.1080/01587919.2019.1656151 